This item is the archived peer-reviewed author-version of:

The urban history of the medieval Low Countries: research trends and new perspectives (2011-2018)

\title{
Reference:
}

Puttevils Jeroen.- The urban history of the medieval Low Countries: research trends and new perspectives (2011-2018)

Urban history - ISSN 0963-9268 - 46:3(2019), p. 542-554

Full text (Publisher's DOI): https://doi.org/10.1017/S0963926819000403

To cite this reference: https://hdl.handle.net/10067/1596650151162165141 
Urban history of the medieval Low Countries: research trends and new perspectives (2011-2018)

\section{Jeroen Puttevils}

2019 marks the centenary of the Dutch historian Johan Huizinga's famous Herfsttij der Middeleeuwen: Studie over levens- en gedachtenvormen der veertiende en vijf- tiende eeuw in Frankrijk en de Nederlanden (The Waning of the Middle Ages: A Study of the Forms of Life and Thought in the Fourteenth and Fifteenth Centuries in France and the Netherlands). In the first chapter of this book, Huizinga writes:

Between town and country, too, the contrast was very marked. A medieval town did not lose itself in extensive suburbs of factories and villas; girded by its walls, it stood forth as a compact whole, bristling with innumerable turrets. [...] The contrast between silence and sound, darkness and light, like that between summer and winter, was more strongly marked than it is in our lives. The modern town hardly knows silence or darkness in their purity, nor the effect of a solitary light or a single distant cry. ${ }^{1}$

Huizinga's nostalgic description of the late-medieval town sets the urban setting apart from its rural surroundings and other milieus. In the remainder of the book the urban nature of the Low Countries is only very sparsely alluded to. Johan Huizinga may have been the founder of the fields of cultural history and the history of mentalities, but he was not a historiographical protagonist in the development of urban history. This was in contrast to his Belgian contemporary Henri Pirenne, whose work on medieval urban democracies and the social and economic ups and downs of cities in the Low Countries continues to be an influence for urban historians today. Huizinga might even be called an anti-hero of urban history as it is practiced today. His critics have pointed out Huizinga's lack of interest $\mathrm{n}$ the different characteristics of social groups (privileging royalty and the aristocracy in The Waning of the Middle Ages), his unwillingness to identify different paths of historical change, focusing on the decay - in his eyes - of the late medieval period, and perhaps fundamentally for this review, his disregard for the power and importance of urban culture in the Burgundian realm. ${ }^{2}$ Huizinga may thus have found little to like in (aspects of) the recent PhD-work on medieval urban history surveyed here. The firm source basis of these dissertations, often built on extensive and impressive purpose-built databases, would likely not have struck a chord with Huizinga who preferred a more intuitive and empathic approach. Yet, he would surely have appreciated the current focus on the later Middle Ages and the openness to insights from other disciplines such as archaeology, sociology, political theory and theories of memory, present in the many PhD-dissertations on medieval urban history in the Low Countries. All of these dissertations examined here provide fresh insights and are constitutive of recent directions in this field.

It is now eight years since Jelle Haemers examined the postgraduate work produced on the urban history of the medieval Low Countries in this journal and, with this in mind, this review builds on the work he began. ${ }^{3}$ However, it reflects the changing trends in the scholarship too. In section one I

\footnotetext{
${ }^{1}$ J. Huizinga, The waning of the Middle Ages: a study of the forms of life, thought and art in France and the Netherlands in the fourtheenth and fifteenth centuries (Harmondsworth, 1955), $367 \mathrm{p}$.

2 E. Peters and W. P. Simons, 'The New Huizinga and the Old Middle Ages', Speculum, 74 (1999), 587-620, M. Boone, 'L'automne du Moyen Age': Johan Huizinga et Henri Pirenne ou 'plusieurs vérités pour la même chose' In P. Moreno and G. Palumbo (eds.), L'automne du Moyen Age. Textes, iconographie, philologie. Journées pour Alberto Varvaro (chaire Francqui au titre étranger 2003-2004) (Genève, 2005), 27-51.

${ }^{3}$ Recent monographs and articles which were published since 2011 and that are indicative of the trends seen in the theses are included in the footnotes (they are not extensively discussed in the text). The recent publication of two syntheses (in English) on the medieval history of the urban Low Countries is strong proof that this a lively field: B. Blondé, M. Boone and A.-L. Van Bruaene (eds.), City and Society in the Low Countries, 1100-1600
} 
examine the work done on urban material culture, whilst section two deals with economic shifts in the region. Section three discusses urban governance and in the last section I give an overview of the theses on memory and poor relief.

\section{True colours: late medieval urban material culture}

Johan Huizinga was impressed by the art of the later Middle Ages, especially by its combination of realism and symbolism, its colourfulness. Indeed, it was a visit to an art exhibition on the so-called Flemish Primitives in Bruges which produced the historical sensation which led Huizinga to write The Waning. Historians and historians of art nowadays consider famous pieces of art, such as the paintings of Van Eyck, Van der Weyden and Memling, as part of a wider material culture. The recent research on material culture in the medieval Low Countries is hemmed in between historiography on renaissance Italy on the one hand and the seventeenth- and eighteenth-century Dutch Republic on the other. ${ }^{4}$ For Italy, Jacob Burckhardt and more recently Richard Goldthwaite have laid bare the connection between the consumption patterns of urban elites (who had an income large enough to pay for this magnificence and splendour) and the rise of Renaissance culture. ${ }^{5}$ Jan De Vries places the cradle of modern consumer society in the seventeenth-century Dutch Republic. ${ }^{6}$ These consumers were, however, no longer just found amongst the elite. Consumption of inexpensive consumer goods that brought comfort and pleasure and created domesticity spread out to a much more socially diverse group of consumers. A recent project at the Centre for Urban History at Antwerp investigated precisely the social foundations and repercussions of changes and continuities in late medieval material culture in Low Countries cities by analyzing hundreds of inventories, both post-mortem and after confiscation. This enterprise has resulted in three different Ph.D.-dissertations which respectively focused on the clothing (Isis Sturtewagen), cooking and dining (Inneke Baatsen) and the organization of spaces and decorations within the house (Julie De Groot). ${ }^{7}$ Although the three dissertations rely on the same database of inventories, each dissertation tackles different debates - on fashion, the relation between social manners and material culture, functional specialization within the house and domesticity - all while relying on strong empirical foundations: the collective database of inventories supplemented (in different degrees in each dissertation) by visual evidence from paintings by the Flemish Primitives and from prints, etiquette literature, cookbooks, contemporary literature, extant material objects and archaeological reports. The three dissertations also link the material culture found in the inventories to different social groups, categorized according to the number of rooms mentioned in the inventory, which serves as a proxy for wealth.

Isis Sturtewagen's dissertation corrects the common cliché that the clothing of non-elite citizens was dull and drab. Lower income and middling groups were dressed in the same colours as elites. What made for social differentiation was the intensity and quality of the dye and the fabric (silk,

(Cambridge, 2018), V. Lambert and P. Stabel (eds.), Golden Times: Wealth and status in the Middle Ages in the southern Low Countries (Tielt, 2016).

${ }^{4} \mathrm{M}$. Howell, Commerce before capitalism in Europe, 1300-1600 (Cambridge, 2010), B. Blondé and W. Ryckbosch, 'In 'splendid isolation'. A comparative perspective on the historiographies of the 'material renaissance' and the 'consumer revolution", History of Retailing and Consumption, 1 (2015), 105-124.

${ }^{5}$ R. A. Goldthwaite, Wealth and the demand for art in Italy, 1300-1600 (Baltimore, Md, 1993).

${ }^{6} \mathrm{~J}$. de Vries, The Industrious Revolution: consumer behavior and the household economy, 1650 to the present (Cambridge, 2008).

${ }^{7}$ I. Sturtewagen, 'All together respectably dressed: fashion and clothing in Bruges during the fifteenth and sixteenth centuries' (University of Antwerp PhD, 2016), I. Baatsen, 'A bittersweet symphony: The social recipe of dining culture in late medieval and early modern Bruges (1438-1600)' (University of Antwerp PhD, 2016), J. De Groot, 'At home in Renaissance Bruges: Material and domestic culture in a city in decline, 1438-1600' (University of Antwerp PhD, 2017). 
mixed textiles and woollens). Moreover, small decorations could be added; the right accessories mattered too in late medieval Bruges. The deterioration of Bruges' economy in the sixteenth century clearly affected incomes and the clothing that Bruges citizens were able to wear. Yet, not only income determined what Bruges' people wore. The occasion, age, gender, marital status and general decorum mattered as well. It is these factors, and not the fairly weak sumptuary laws of the Low Countries, which determined what fifteenth- and sixteenth-century inhabitants of Bruges wore. In any case, the Bruges example demonstrates that there was no such thing as the gradual democratization of fashion. Inneke Baatsen shows that dining practices were strongly interwoven with the social dynamics of urban society: tastes, modes of dining, use of table utensils and dining settings changed considerably in the fifteenth and sixteenth centuries and differed along social lines. Rich households had separate dining rooms, some of them even reserved for special occasions, while the less well-off ate in their kitchens. Yet at the same time, kitchens became convivial spaces as well. What was on the table - and especially the quality of the dishes and the refinement of the vessels - also signified social identity. Moreover, dining culture individualized, with each dining guest starting to have an individual plate and utensils. Table manners too signified social and cultural capital and became an indicator of growing social polarization. Julie De Groot draws on the place descriptions and room labels in the inventories to reconstruct the lay-out of Bruges houses. Doing so, she catches a glimpse of the actual use, context and lived reality of the decorative objects figuring in the inventories. Paintings, for example, were often clustered around house altars, indicating the degree of private devotion of the inhabitants of late medieval Bruges. The debate on the history of domesticity is fraught by the difference between public and private and Bruges' houses often had both dimensions. A public environment, like a shop, workshop or office, and more separate, domestic spheres. Besides growing functional specialization in larger houses - each room had an exclusive function, for example: there were no beds in the kitchen, there was social specialization: certain rooms to be used at certain times and by certain people. Bruges citizens consciously furnished and organized their house and transformed it into a home. All three dissertations compare their findings on Bruges with other cities in the Low Countries and abroad while at the same time emphasizing the particular context and evolution of Bruges society reflected in its material culture. Surely, a twenty-first-century Johan Huizinga would have appreciated the sensitivity to materiality, colour, cultural practices and domesticity.

\section{Economic shifts}

Late medieval Bruges and its economy in particular, producing the material culture described in the previous section, looms large in the flurry of other dissertations on medieval urban history in the Low Countries. ${ }^{8}$ Botho Verbist draws on a complex database based on the extensive account ledgers of the Bruges broker Wouter Ameyde, active in the final years of the fifteenth and the first of the sixteenth century, to analyse the important role of brokers on the Bruges market and the use of double-entry bookkeeping. Traditionally, brokers in fifteenth-century Bruges have been characterized as an old and parasitic institution: they were rent-seekers who were no longer necessary in a commercial city where ever more foreign merchants resided on a permanent basis. This alleged conservatism would eventually spell the demise of the Bruges market, when, throughout the fifteenth century, merchants started to frequent the more liberal Brabant fairs, an argument put forward by, among others, Henri Pirenne. ${ }^{9}$ Verbist demonstrates that brokers became increasingly specialized into certain commodities: Ameyde established close contacts with producers in Bruges' industrial hinterland and countryside and

\footnotetext{
${ }^{8}$ A. Brown and J. Dumolyn (eds.), Medieval Bruges, c. 850-1550 (Cambridge, 2018).

${ }^{9} \mathrm{H}$. Pirenne, Les villes du Moyen: essai d'histoire économique et sociale (Paris, 1927) \& the overview of the literature in J.L. Bolton and F. Guidi Bruscoli, "When did Antwerp replace Bruges as the commercial and financial centre of north-western Europe? The evidence of the Borromei ledger for 1438" The Economic History Review 61, no. 2 (2008): 360-79.
} 
offered access to this supply network to his clients. Brokers like Ameyde offered legal guarantees, representation, and payment services, at low fees. As such, these brokers remained valuable to traders, many of them who stayed in Bruges throughout the trade year. Moreover, the brokers became merchants themselves, a clear indication of the need to rethink the historiography on medieval Bruges as a centre of commerce dominated by foreign traders. Verbist emphasizes the discursive function of medieval accounting: written accounts, especially when structured according to the principles of double entry, acted as proof and signalled a reputation of honesty and professionalism towards the clients, often foreigners, of Bruges brokers and innkeepers. This type of book-keeping was also used in pragmatic fashion: book-keepers like Ameyde adapted the system to their own needs, which could change over time. ${ }^{10}$

Bruges and its outport system in the Zwin estuary has also drawn the attention of archaeologists in recent years. Jan Trachet, together with colleagues from archaeology, history and geology, laid bare (pun intended since this research builds mainly on non-invasive state-of-the-art archaeological techniques) the changes in the Zwin landscape between 700 and 1550 . Focusing on Michem, Monnikerede and Hoeke, the archaeological evidence shows how Bruges' growing importance as a commercial town was made possible by the alteration of the landscape, from a coastal to a port environment. Bruges' $15 \mathrm{~km}$ distance from the shore enhanced the development of a string of outports along the Zwin. The topography of these outports is now clearly established. Bruges' trade links are clearly observable in the archaeological remains found in the Zwin such as "exotic" cobblestones from the region around Berwick-upon-Tweed and the beaches of the Baltic Sea used as ship ballast by Hanseatic traders; vice versa, Flemish sand is found at Wismar. ${ }^{11}$

Shifts in commercial activity were not limited to Bruges' outports and there has been considerable recent debate on the relocation of the commercial gateways in the Low Countries in the fifteenth and sixteenth centuries. ${ }^{12}$ Bruges had to give way to Antwerp after the revolts of the last two decades of the fifteenth century, while the Dutch Revolt toppled Antwerp to the benefit of Amsterdam. Such divergent trajectories of particular cities are methodologically instrumentalized in several of the dissertations reviewed here. Andrea Bardyn's is one of them. She tackles one of the big questions in the historiography on the late medieval economy: how did women fare in the urban economy after the Black Death? The Brabant towns of Leuven, in economic decline during the second half of the fifteenth century, and Antwerp with a booming commercial economy in that same period figure as case studies. As such, Bardyn takes on other towns that the well-studied Flemish cities. Besides differing economic structures and development, customary laws and political events were different as well and all clearly affected women's agency in these towns. Contrary to most recent work on women's agency in the post-Black Death economy which emphasizes the labour market, Bardyn focuses on their participation on the financial and real estate market. While women's legal position was declining in the later Middle Ages, exactly the opposite happened in cities such as Antwerp where women's capital was drawn into the growing commercial economy. What clearly mattered for participation and their capacities in the financial market was the life-stage at which they found themselves. Previous work has highlighted rich widows but single - beguines included - and married women were not to be ignored

\footnotetext{
${ }^{10}$ B. Verbist, 'Traditie of innovatie? Wouter Ameyde, een makelaar in het laatmiddeleeuwse Brugge, 14981507' (University of Antwerp PhD, 2014).

${ }^{11} \mathrm{~J}$. Trachet, 'Inland outports: An interdisciplinary study of medieval harbour sites in the Zwin region' (University of Ghent PhD, 2016).

${ }^{12} \mathrm{O}$. Gelderblom, Cities of commerce: the institutional foundations of international trade in the Low Countries, 1250-1650 (Princeton, 2013), J. Puttevils, Merchants and Trading in the Sixteenth Century: The Golden Age of Antwerp (London, 2015), W. Blockmans, Metropolen aan de Noordzee: de geschiedenis van Nederland, 1100 1560 (Amsterdam, 2010).
} 
in this market. An important finding of this study is that men spread their investments over annuities, real estate and short-term loans whereas women usually only engaged in long-term money-lending in return for a fixed annual income. Some women were active investment managers, unlike the passive and "incompetent" female bearers of lineage assets found in other Low Countries towns. The evidence from Antwerp's growing economy and more lenient legal system shows that the patriarchal restructuring of property was not a general phenomenon across the Low Countries during the fifteenth century, it was specific to particular contexts, mainly those of industrial decline in the textile sectors and weakening urban middle groups. ${ }^{13}$

Besides the private market for finance and real estate, registered in the aldermen's deeds registers used by Bardyn, there was also a lively market for public credit in the towns, registered in the city accounts. Rudolf Bosch taps into these sources and into the rich historiography on urban finances in Flanders, Brabant and Holland. The originality of his dissertation lies in the selection of two towns, Arnhem and Zutphen, in the duchy of Guelders in the fourteenth to sixteenth centuries, a land-locked political entity outside of the maritime core of the Low Countries, usually considered as peripheral by historians of the medieval Low Countries. Here again an intercity comparison forms the crux of the dissertation. Arnhem and Zutphen retained more financial autonomy than towns in Flanders, Brabant and Holland, even if the Counts and Dukes of Guelders wanted to tap into urban credit, capital and taxes to pay for their wars as much as their Burgundian competitors, they were much more dependent on their domain. ${ }^{14}$ Another difference was the relatively late (end of the fifteenth century) demand for insight in and control of the city accounts by craft guilds. This was also the period when urban finances deteriorated as the result of increasing loans and gifts to the duke. The Guelders towns allied with their duke to keep out Burgundian rule after the traumatic Burgundian occupation of 1473-77. Guelders' urban elites chose to increase taxes to support the Duke, while at the same time making sure that their Prince did not become too strong through the renewal of existing and acquisition of new urban privileges. The characteristics of urban finances were thus similar to those of other Low Countries' towns: predominant indirect taxation based on excises and the use of funded urban debt as extraordinary revenue in times of need. ${ }^{15}$

\section{Urban governance}

The same desire to compare different towns and to include historiographically more peripheral regions is to be found in the dissertation by Ben Eersels on the participation of craft guilds in the urban government of Leuven (Duchy of Brabant), Maastricht (a double lordship with feudal ties to both the Duke of Brabant and the Prince-Bishop of Liège) and Sint-Truiden (Prince-Bishopric of Liège) in the fourteenth and fifteenth centuries. ${ }^{16}$ Central questions in this dissertation are the degree of participation of certain craft guilds, the identity of craft guild figures in urban government, the political

\footnotetext{
${ }^{13}$ A. Bardyn, 'Women's fortunes: Gender differences, property, and investment in late medieval Brabant' (KU Leuven PhD, 2018).

14 R. Stein, Magnanimous Dukes and Rising States: The Unification of the Burgundian Netherlands, 1380-1480 (Oxford, 2017).

${ }^{15}$ R. Bosch, 'Stedelijke macht tussen overvloed en stagnatie: Stadsfinanciën, staatsvorming en economie in het hertogdom Gelre, ca. 1350-1550' (University of Groningen PhD, 2018). See also: 22 R. van Schaik (ed.), Economies, Public Finances, and the Impact of Institutional Changes in Interregional Perspective: The Low Countries and Neighbouring German Territories (14th-17th centuries) (Turnhout, 2015), J. Hanus, Tussen stad en eigen gewin: stadsfinanciën, renteniers en kredietmarkten in 's-Hertogenbosch (begin zestiende eeuw) (Amsterdam, 2007).

${ }^{16} \mathrm{~B}$. Eersels, 'The craft guilds are the city: political participation in late medieval towns, Brabant and Liège (c. 1360-1500)' (KU Leuven PhD, 2018). The Duchy of Brabant also features in V. Vrancken, De Blijde Inkomsten van de Brabantse hertogen: Macht, opstand en privileges in de vijftiende eeuw (Brussel, 2018).
} 
agendas of craft guilds, the strategies used to secure demands and the channels of communication to voice these agendas and demands. Leuven, and Brabant in general, witnessed fewer revolts than the county of Flanders or the Liège region because of its reliance on diplomatic means, based on constitutional texts balancing the powers of the different political stakeholders in the duchy. The prince-bishopric of Liège was characterized by an almost constant succession of revolts caused by a large number of political actors of which none was able dominate the others (prince-bishops, towns, invading foreign princes). Whereas political life in the county of Flanders and the city of Liège are common subjects in political historiography, civic political participation - all activities that citizens undertook to influence governmental decisions in a relatively direct manner - through craft guilds in Brabant and other Liègeoise towns remains unexplored. Participation by craft guilds in urban government in the three towns was never a given; formal representation of craft guilds in the city council could be revoked and regained afterwards. Contrary to previous studies on Flemish towns, Eersels prosopographic research shows the absence of a process of oligarchization of urban government; there was a high turnover of craft guild members who acted as guild representatives in the city council, most of whom were middle-class with strong networks rather than wealthy members who simply used guild membership for access to urban power. In all three cities, the urban government consulted with and was petitioned by the craft guilds, which demonstrates the latter's influential position in urban politics. Yet one should not characterize these craft guilds as democratic: while craft guilds often represented themselves as the heeders of the common good, lower-status artisans and non-members were kept outside of the political process in which guilds participated. Moreover, other organizations such as parishes or neighbourhoods were excluded from political power by the craft guilds which claimed to speak on behalf of the urban commune. This dissertation reflects the current characterization of medieval urban politics as poly-nuclear: power was shared and disputed by different organizations which themselves were dominated by intra-group struggles. ${ }^{17}$

Janna Coomans tackles the preoccupation with the common good in cities of the fourtheenth- and fifteenth-century Low Countries from a totally different angle: urban public health. Medieval historians collectively sigh when confronted with a popular imagination that constructs medieval cities as filthy and disease-ridden and Coomans demonstrates that urban authorities took significant actions to improve public health. The study argues that actions undertaken to improve urban health and sanitation had a strong impact on the governance of the urban population and social practices. The actions themselves were the object of negotiation between different urban groups. Drawing on a mixed theoretical framework which borrows from theories of space, governance, Michel Foucault's concept of biopower and actor-networks, and on a robust source-base with three detailed case studies of Ghent, Leiden and Deventer. Alongside the secondary literature on the entire Low Countries, the reader gets to know what the perceived challenges to public health were, how these were dealt with and how this impacted the cities politically, socially and economically. What comes of this research is that responses to public health problems were not ad-hoc, but a consistent and routine intervention of urban authorities. The Black Death may have been a sizeable challenge, but the policing of public health clearly predated the epidemic. To understand medieval public health, one should also consider the roles of fire, military threats, access to and quality of water (and in the context of the Low Countries, protection against water), food production and quality, garbage disposal, pig-keeping and stray dogs and even migration and prostitution. Through measures on all these domains, urban authorities intervened in what we today would see as the private spheres of urban inhabitants; they justified these actions through emphasizing how they contributed to communal well-being. To enforce the rules, urban governments relied on specialized supervisors, urban officials such as market

\footnotetext{
17 P. Lantschner, The Logic of Political Conflict in Medieval Cities: Italy and the Southern Low Countries, 13701440 (Oxford, 2015).
} 
overseers adding public health to their task agenda and talebearers who received part of the fine. Urban governments also co-operated with individual petitioners, informal networks, neighbourhood organizations and guilds. This investigation into medieval public health has led us to a better understanding of government interventions into the lives of urban dwellers and on the way public health affected urban space. ${ }^{18}$ This attention to the interplay between mentality and practice would have pleased Huizinga.

\section{Memory and poor relief}

Memory or memoria - obviously a topic of interest to Huizinga as a historian of mentality - has been the subject of considerable research in the urban history of the Low Countries over the last few years. ${ }^{19}$ Tineke Van Gassen's PhD-dissertation provides an in-depth insight in the documentary memory of the late-medieval city of Ghent (fourteenth to sixteenth centuries). Where, how and why did Ghent's city government kept, ordered and inventoried its charters, privileges, cartularies and administrative documents and what role did these documents play in the city's turbulent political history? What was the function of a medieval city archive? These questions mirror recent research on the social history of premodern archives..$^{20}$ Hence, this study brings together urban history, history of administration and archives, mnemonic practices, the increasing reliance on writing, and the study of social identities. This is a field of research that is not strongly developed in the southern Low Countries, where the archival practices of rulers and religious institutions have drawn much more attention. While this is a study of Ghent, Van Gassen compares her findings with the archival situation in that other important Flemish city, Bruges. Ghent's city government went to great lengths to protect its important documents: they were kept in treasure boxes under lock and key in closed-off rooms. Different urban officers each had a key and the treasure boxes could only be opened when all keys were present. The distribution of the keys reflected the distribution of urban political power. Interestingly, Ghent's urban archive was first located in the tower of the Church of Saint-Nicolas, to be moved to the Franciscan monastery in the fourteenth century. Only at the beginning of the fifteenth century was the archive transferred to Ghent's belfry. Van Gassen observes that initiatives to copy important texts and privileges and inventory of the archive almost always took place in years of political crisis. She shows that the archive as a form of urban social memory could be weaponized for political purposes. This dissertation also brings together and provides detailed analyses of a large range of urban documents which will be of interest to many urban historians. ${ }^{21}$

Hannelore Franck considers another facet of memory in the late-medieval towns of the Low Countries: the relation between remembrance and care for the afterlife or memoria in the medieval sense on the one hand and caritas or poor relief on the other. She investigates anniversaria - masses for the salvation of oneself or others on an annual or more frequent basis - at parish poor tables in the city of Bruges between 1270 (the first year of documentation relating to the institution of a parochial poor table) and 1584 (the end of the Bruges Calvinist republic). Many memorial services had a charity component: annuities, tithes or sums of cash paid for the foundation and allowed the poor table to distribute bread or other foodstuffs among the parish poor to increase the number of mass attendants

\footnotetext{
18 J. Coomans, 'In Pursuit of a Healthy City: Sanitation and the Common Good in the Late Medieval Low Countries' (University of Amsterdam PhD, 2018).

${ }^{19}$ Related to memory is Matthew Champion's monograph on temporalities in the fifteenth-century Low Countries: M. S. Champion, The fullness of time : temporalities of the fifteenth-century Low Countries (Chicago, 2017).

${ }^{20}$ L. Corens, K. Peters and A. Walsham (eds.), The Social History of the Archive: Record-Keeping in Early Modern Europe, Past \& Present Supplement, 230, 11 (2016).

${ }^{21} \mathrm{~T}$. Van Gassen, 'Het documentaire geheugen van een middeleeuwse grootstad: ontwikkeling en betekenis van de Gentse archieven' (University of Ghent PhD, 2017).
} 
:the more prayers, the greater chances for the founder's salvation. Poor relief by parish institutions is at the intersection of different historiographical traditions: studies into poor relief, civic religion, community formation, as well as religious and ecclesiastical history. However, Franck asserts that the precise connection between liturgy and poor relief and its long-term evolution has not received enough attention. Bruges constitutes an excellent case study for several reasons: the wealth of a commercial metropolis made for well-endowed and hence well-documented parish poor tables. The growing influence of Protestantism which culminated in a Calvinist republic (1578-1584) which obviously also affected the working of the Catholic parish poor tables and the pioneering role of the Western Flemish region in poor relief reforms in the sixteenth century. The main finding of this study is the constancy of the relationship between caritas and memoria, even when religious crisis struck the city. The poor tables retained a fairly high degree of autonomy over time while at the same time they maintained ties with the urban and church governments and other charity and corporative organisations in Bruges. Even in the sixteenth century when voices for centralization of poor relief became louder, these organisations displayed a remarkable resilience; although, in the end, the poor tables had to seize control and autonomy. In theory, donations were eternal but poor tables reduced, compounded and sometimes even stopped certain foundations. At risk were those foundation of which the value decreased in real terms over time (annuities and tithes). Donors, therefore, started to use lump cash sums. The question remains whether the poor relief financed by foundations was sufficient. Poor tables were able to increase poor relief for short periods, but were ineffective because of their fixed income in longer periods of crisis. The profile of the donors changed over time: in the fourteenth and sixteenth century they mostly came from the urban elites, but in the fifteenth century, resulting from the economic boom, it was mainly the upper middle class which founded many requiem masses and contributed to urban poor relief. The donors were obviously concerned with their own salvation and instrumentalized poor relief to achieve this. Yet there was more to their apparent generosity: large donations bestowed prestige and status on the donor. The number and value of the foundations also waxed and waned along lines of economic conjuncture of Bruges. ${ }^{22}$ The similar study by Douwe Faber on late-medieval Leiden largely confirms Franck's findings. In Leiden, however, the control by the city government on the relations between founders, poor tables, church fabrics and ecclesiastical authorities was larger than in Bruges. Faber's study (as does Franck's) also demonstrates the omnipresence and frequency of annual masses in cities. ${ }^{23}$

Whereas Franck and Faber focus on one city (which they obviously compare with others through secondary literature), Auke Rijpma takes a wider perspective in several senses: his dissertation deals with several towns and regions in the Low Countries (Leiden, Utrecht, Gent and their surrounding countryside), considers the connection between religious and charitable foundations and the provision of public services, including poor relief and religious services, but also education, and deals with poor tables, hospitals, monasteries, chapters, church fabrics and benefices. While Franck and Faber can be characterized as religious and social history, Rijpma's work is very much economic history (based as it is on extensive quantitative analysis). The central question of this work is the extent to which religious and charitable institutions provided public services, how these services were financed and whether regional differences could be observed. Large foundations and rural foundations mainly drew their income from land, ownership whereas annuities (usually also based on land) were equally important for urban foundations. Smaller gifts were especially important for church fabrics and poor tables.

\footnotetext{
${ }^{22} \mathrm{H}$. Franck, 'Caritas et Memoria. Een studie naar de samenhang tussen armenzorg en memorieviering in de kosmopolitische stad Brugge tijdens de late middeleeuwen - vroegmoderne periode aan de hand van de organisatie en werking van de parochiale dissen' (KU Leuven PhD, 2018).

${ }^{23} \mathrm{D}$. Faber, 'Memoria in Leiden in de late Middeleeuwen. Stichten en bespreken. Samenwerken en betwisten' (Utrecht University PhD, 2018).
} 
Rijpma shows that particular foundations spent income on particular kinds of services: church fabrics, for example, financed education. Aggregating a large amount of data, it becomes clear that social expenditure was highest (on a per capita level) in cities without a strong industrial sector but with a role of power for guilds. ${ }^{24}$

Johan Huizinga would, I hope, be pleasantly surprised to see the variety and depth of current research on medieval urban history in the Low Countries, a history which he was reluctant to include in his Waning of the Middle Ages. A willingness to compare several cities or to focus on one city and consider it within the framework of the European urban historiography, the strong foundations of these studies built on extensive archival research and an openness to theories from other fields of history and others sciences are the key strengths of all these PhD-dissertations covered in this review. In 2011 Jelle Haemers' review, observed the growing importance of new methods: prosopography, discourse analysis and social network analysis to name a few. These methods are present in the theses considered here as well and continue to augment the arsenal of the urban historian. Many of the reviewed dissertations have engaged in the construction of large, sophisticated databases which produce detailed statistical data. What is perhaps still missing is the implementation of advanced methods from digital humanities: transcribing is still done in the old fashioned manner, there is no digital text corpus analysis and GIS is not exploited in most theses. ${ }^{25}$ This does not downplay the quality of the research and maybe the research is still best done by drawing on traditional methods. The future (and, one hopes another of these reviews) will show whether medieval urban historians in the 2020s will work very differently than this bright generation.

\footnotetext{
${ }^{24} \mathrm{~A}$. Rijpma, 'Funding public services through religious and charitable foundations in the late-medieval Low Countries' (Utrecht University, 2012).

${ }^{25}$ D. J. Birnbaum, S. Bonde and M. Kestemont (eds.), The Digital Middle Ages: A Speculum Supplement (Chicago, 2017).
} 